Web Jurnal:

http://ejournal.kemenperin.go.id/jli

Kementerian

Perindustrian

REPUBLIK INDONESIA

\title{
Rancang bangun titrator otomatis untuk alat uji kalium iodat dalam garam konsumsi beriodium
}

\section{Design of potassium iodate test equipment in iodized salt using an automatic titrator}

\author{
Ardhaningtyas Riza Utami* dan Deny Suryana \\ Balai Riset dan Standardisasi Industri Surabaya \\ Jl. Jagir wonokromo 360, Surabaya, Indonesia \\ *email:riza2308@gmail.com
}

\begin{tabular}{|c|c|}
\hline INFO ARTIKEL & ABSTRAK \\
\hline Sejarah artikel: & Penelitian ini membuat alat uji kalium iodat dalam garam konsumsi beriodium dengan \\
\hline Diterima : & menggunakan titrator otomastis yang dirancang dengan mengacu pada metode titrasi \\
\hline 11 Januari 2021 & sesuai SNI 3556-2010. Alat uji ini dilengkapi dengan sensor warna RGB TCS230 dan \\
\hline Direvisi : & step counter untuk mendeteksi volume titran yang digunakan. Sensor warna RGB TCS \\
\hline 31 Mei 2021 & 230 tersebut akan membaca perubahan warna endpoint proses titrasi dan memberikan \\
\hline $\begin{array}{l}\text { Diterbitkan : } \\
30 \text { Juni } 2021\end{array}$ & perintah untuk menghentikan titrasi. Informasi volume yang diteteskan stepcounter \\
\hline & $\begin{array}{l}\text { disampaikan ke software yang telah dibangun di mikrokontroler ATMEGA328 PDIP } \\
\text { untuk dihitung kadar kalium iodat dalam sampel garam. Titrator otomatis kalium iodat }\end{array}$ \\
\hline $\begin{array}{l}\text { Kata kunci: } \\
\text { garam beriodium; } \\
\text { kalium iodat; } \\
\text { titrator otomatis; }\end{array}$ & $\begin{array}{l}\text { yang dirancang dapat bekerja dengan baik memberikan hasil uji verifikasi metode yang } \\
\text { memenuhi syarat keberterimaan akurasi, presisi dan reproducibility. \% Recovery hasil uji } \\
\text { akurasi mencapai } 99,52 \% \text {, uji presisi didapatkan nilai } \mathrm{RSD}_{\text {contoh }}<\mathrm{CV}_{\text {repeatability, yaitu } 4,23} \\
<6,31 \text {, Uji reproducibility didapatkan nilai } \% \mathrm{RSD}<0,5 \mathrm{CV}_{\text {horwitz }} \text { yaitu } 2,058<6,202 \text {. }\end{array}$ \\
\hline
\end{tabular}

sensor warna

\section{ABSTRACT}

iodized salt; potassium iodate; automatic titrator; color sensor

\begin{abstract}
The purpose of this study was to develop an instrumentation for the determination of potassium iodate in iodized salt using an automatic titration which refers to the titration method according to SNI 3556-2010. This instrumentation was equipped with a TCS230 $R G B$ color sensor and a step counter to detect the volume of the titrant used. The TCS $230 R G B$ color sensor was reading the end point color changes of the titration process and gave commands to stop the titration. The information on the volume that was dropped by the stepcounter was conveyed to the software that has been built in the ATMEGA328 PDIP microcontroller to calculate the potassium iodate levels in the salt sample. The designed potassium iodate automatic titrator was working well which was indicating acceptable verification data for accuracy and precision including repeatability and reproducibility. \% recovery of the accuracy test results reached $99.52 \%$, the precision test obtained the value of $R S D_{\text {example }}<$ CVrepeatability, that is $4.23<6.31$, the reproducibility test obtained the value of $\% R S D<0.5 C V_{\text {horwitz, }}$ that is $2.058<6.202$.
\end{abstract}

(C) 2021 Penulis. Dipublikasikan oleh Baristand Industri Padang. Akses terbuka dibawah lisensi CC BY-NC-SA

\section{Pendahuluan}

Garam adalah sejenis mineral alam berbentuk kristal putih yang dihasilkan dari proses penguapan air laut dan dikonsumsi oleh manusia sebagai bumbu masak atau sebagai pengawet makanan (Mahlinda dan Lancy, 2013). Garam merupakan salah satu bahan tambahan makanan yang digunakan oleh manusia sebagai pemberi cita rasa. Kalium Iodat $\left(\mathrm{KIO}_{3}\right)$ merupakan salah satu zat yang harus ada pada garam konsumsi beriodium (Amanati 2017). Berdasarkan hasil penelitian diperoleh data konsumsi garam rata-rata pada manusia adalah 7,3 gram/hari. $81,1 \%$ mempunyai kadar iod rendah dan 
18,9\% mempunyai kadar iod cukup, (Irawati et al., 2011).

Penambahan $\mathrm{KIO}_{3}$ dalam garam konsumsi beriodium merupakan salah satu upaya pemerintah untuk mengatasi Gangguan Akibat Kekurangan Iodium (GAKI), (Amanati 2017). GAKI merupakan masalah gizi utama di Indonesia, begitu juga di dunia. GAKI dapat berdampak pada semua kalangan usia, baik pada janin, bayi, anak, remaja maupun dewasa. GAKI yang paling sering terjadi di berbagai kalangan usia adalah gondok, (Lathifah 2018).

Keputusan Presiden No. 69 tahun 1994 tentang pengadaan garam beriodium menegaskan bahwa garam yang dapat diperdagangkan bagi keperluan konsumsi manusia, pengawet makanan atau bahan penolong industri pangan adalah garam beriodium yang telah memenuhi Standard Nasional Indonesia (SNI). SNI wajib untuk garam konsumsi beriodium mengacu pada SNI 3556. Berdasarkan SNI tersebut, kadar minimum iodium yang ada di dalam garam konsumsi adalah 30 $\mathrm{mg} / \mathrm{kg}$.

Iodium adalah unsur gizi mikro yang berfungsi untuk pembentukan hormon tiroid, tiroksin $\left(\mathrm{T}_{4}\right)$ dan triiodotironin $\left(\mathrm{T}_{3}\right)$ yang berguna dalam proses pengembangan susunan syaraf pusat dan proses tumbuh kembang otak manusia, (Kusuma 2016). Aspek pengolahan garam konsumsi beriodium yang cukup penting dan merupakan critical point dalam produksi garam konsumsi beriodium adalah proses iodisasi, (Lestari 2008).

Jumlah industri garam konsumsi beriodium yang ada sampai saat ini terdiri dari 500 unit industri skala kecil menengah (IKM) dan 10 unit industri skala besar. Dari 510 unit industri garam tersebut, yang sudah mendapatkan sertifikasi SNI mencapai 360 industri. Untuk memenuhi persyaratan kalium iodat $\left(\mathrm{KIO}_{3}\right)$ dalam garam konsumsi beriodium sesuai SNI yang berlaku, maka produsen garam konsumsi beriodium tersebut harus melakukan quality control terhadap produk yang dihasilkan. Namun kendala yang ada saat ini, pelaku industri garam konsumsi beriodium merasa kesulitan untuk melakukan pengujian kalium iodat $\left(\mathrm{KIO}_{3}\right)$ sesuai metode SNI 3556:2010. Sehingga selama ini mereka melakukan pengujian $\mathrm{KIO}_{3}$ dengan menggunakan alat / metode yang tidak baku. Hal ini berdampak pada hasil uji yang mereka dapatkan berbeda jauh dengan hasil uji $\mathrm{KIO}_{3}$ dengan menggunakan metode SNI 3556:2010. Jika hasil uji pengendalian mutu tidak valid, maka hal ini akan berdampak pada kualitas produk yang mereka hasilkan.

Pada umumnya industri garam konsumsi beriodium hanya menggunakan uji kualitatif dengan menggunakan bahan kimia yang diteteskan pada garam dan menunjukkan adanya perubahan warna menjadi ungu jika garam tersebut mengandung iodium. Namun kadar iodium didalam garam tersebut tidak dapat diketahui. Pengujian kalium iodat $\left(\mathrm{KIO}_{3}\right)$ dalam garam konsumsi beriodium, selain menggunakan metode titrasi dapat juga menggunakan metode spektrofotometer pada panjang gelombang $352 \mathrm{~nm}$ dengan menggunakan standard $\mathrm{KIO}_{3}$ sebagai deret kurva kalibrasi (Kapantow dan Yudistira, 2013). Namun metode ini memerlukan instrument spektrofotometer yang harganya sangat mahal, sehingga industri kecil dan menengah merasa kesulitan untuk mengimplementasikan metode spektrofotometer tersebut.

Penelitian ini membuat alat uji $\mathrm{KIO}_{3}$ dengan menggunakan titrator yang dirancang dengan mengacu pada metode titrasi sesuai SNI 3556 : 2010 SNI wajib untuk garam konsumsi beriodium. Dengan demikian diharapkan alat ini dapat dioperasikan secara mudah dan memberikan hasil uji yang valid. Pembuatan titrator otomatis ini sudah pernah dilakukan oleh (Nurmastika et al., 2018) untuk uji asam askorbat pada buah dengan menggunakan sensor warna TCS3200 sebagai inputan data pada actuator. Selain itu (Ika 2009) juga pernah membuat titrator asam basa otomatis dalam mengukur kadar vitamin $\mathrm{C}$ dengan menggunakan sensor conductivity dan sensor $\mathrm{pH}$ sebagai inputan data mikrokontroler. Dalam penelitan tersebut hanya menghitung koreksi kesalahan dalam pengujian dengan membandingkan hasil uji laboratorium / metode manual, namun belum dilakukan pengujian verifikasi dan validasi metode untuk mengetahui kestabilan alat dalam melakukan pengukuran.

Titrator otomatis dalam penelitian ini didesain dengan menggunakan step counter untuk mendeteksi berapa volume titran yang digunakan dan sensor warna TCS 230 untuk mendeteksi terjadinya perubahan warna pada titrasi iodometri dalam pengujian $\mathrm{KIO}_{3}$. Penelitian ini juga melakukan pengujian validasi alat uji dengan pengujian akurasi, presisi dan reproducibility untuk mengetahui kestabilan alat uji. Diagram alir proses pengujian dengan menggunakan titrator otomatis ditampilkan pada Gambar 1.

Prinsip dari penelitian ini adalah menghitung volume natrium tiosulfat yang digunakan untuk menitrasi sampel sampai terjadinya end point titrasi yang ditandai dengan perubahan warna dari ungu menjadi bening. Perubahan warna tersebut dideteksi oleh sensor warna TCS230, kemudian inputan sensor akan mengirimkan informasi ke actuator untuk menghentikan tetesan pompa peristaltik. Volume natrium tiosulfat yang digunakan dideteksi melalui jumlah tetesan yang melewati pompa peristaltic. Natrium tiosulfat yang diteteskan oleh pompa peristaltic telah dikalibrasi terlebih dahulu volumenya, sehingga volume tiosulfat yang digunakan untuk mencapai endpoint titrasi dapat diketahui.

Sensor warna TCS230 adalah sensor warna yang sering digunakan pada aplikasi mikrokontroler untuk pendeteksian suatu obyek benda atau warna dari obyek yang di monitor. Sensor warna TCS230 juga dapat digunakan sebagi sensor gerak, dimana sensor mendeteksi gerakan suatuobyekberdasarkan perubahan warna yang diterima oleh sensor (A.S. Romadhon, 2015) TCS230 yang memiliki respon terhadap panjang gelombang tertentu. Idealnya sumber cahaya yang digunakan adalah cahaya dengan spektrum luas (matahari), namun dalam penelitian ini sumber cahaya menggunakan LED yang mendekati sinar matahari. Warna yang digunakan ada 4 warna, yaitu : merah, biru, hijau, dan putih. Pada dasarnya sensor warna TCS230 adalah rangkaian photodioda yang disusun secara matrik array $8 \times 8$ dengan 16 buah konfigurasi photodioda yang berfungsi sebagai filter warna merah, 16 photodioda sebagai filter warna biru dan 16 photodioda lagi tanpa 
filter warna. Sensor warna TCS230 merupakan sensor yang dikemas dalam chip DIP 8 pin dengan bagian muka transparan sebagai tempat menerima intensitas cahaya yang berwarna(A.S. Romadhon, 2015).

Sensor warna TCS230 bekerja dengan cara membaca nilai intensitas cahaya yang dipancarkan oleh led super bright terhadap objek, pembacaan nilai intensitas cahaya tersebut dilakukan melalui matrik $8 \times 8$ photodioda, dimana 64 photo dioda tersebut dibagi menjadi empat kelompok pembaca warna, setiap warna yang disinari
LED akan memantulkan sinar LED menuju photodioda, pantulan sinar tersebut memiliki panjang gelombang yang berbeda - beda tergantung pada warna objek yang terdeteksi, hal ini yang membuat sensor warna TCS230 dapat membaca beberapa macam warna (Rinaldo et al., 2018). Sensor warna ini digunakan untuk membaca perubahan warna pada saat titrasi, kelebihan penggunaan sensor warna ini lebih peka dan sensitive terhadap perubahan warna.

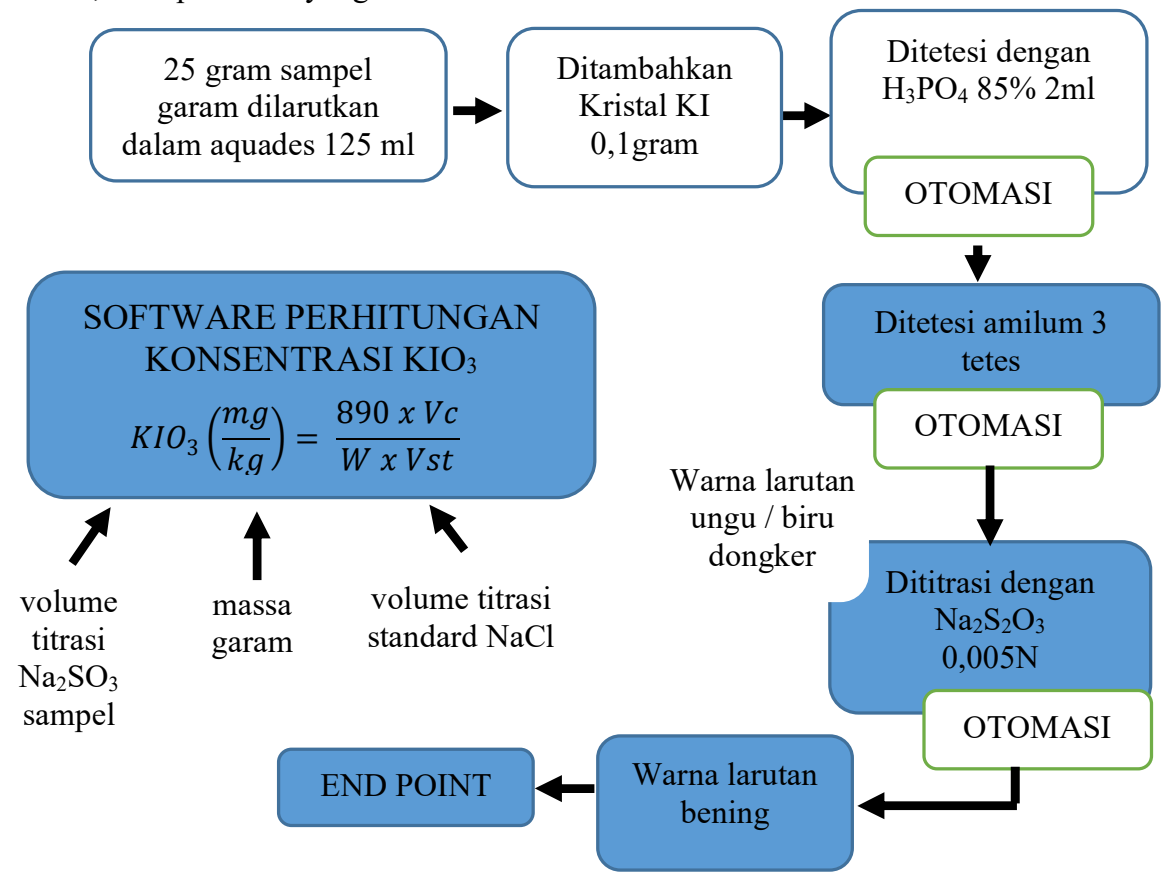

Gambar 1. Diagram alir proses titrasi yang digunakan dalam perancangan titrator otomatis

\section{Metode}

\subsection{Ruang lingkup}

Pembuatan alat ini dilakukan di bengkel Kota Malang. Sedangkan uji coba dan verifikasi alat uji dilakukan di laboratorium uji Baristand Industri Surabaya. Uji coba tersebut meliputi proses running pengujian, perbandingan pengujian $\mathrm{KIO}_{3}$ menggunakan titrator otomatis dan menggunakan metode SNI 3556 : 2010 dan uji coba pengujian standard $\mathrm{NaCl}$. Penelitian ini dilakukan mulai bulan Februari 2019 sampai dengan Desember 2019.

\subsection{Bahan dan alat}

Komponen titrator otomatis dalam yang digunakan dalam penelitian ditampilkan pada Tabel 1. Bahan-bahan kimia yang digunakan untuk pengujian $\mathrm{KIO}_{3}$ dalam garam konsumsi beriodium adalah air suling, $\mathrm{NaCl}$, Larutan $\mathrm{KIO}_{3} 0,005 \mathrm{~N}, \mathrm{H}_{3} \mathrm{PO}_{4} 85 \%$, indicator amylum, Kristal KI dan larutan baku $\mathrm{Na}_{2} \mathrm{~S}_{2} \mathrm{O}_{3} 0.005$ N. Peralatan yang digunakan dalam pengujian $\mathrm{KIO}_{3}$ secara titrasi yang mengacu pada SNI 3556 : 2010, antara lain : Microburet $10 \mathrm{ml}$, neraca untuk menimbang garam, Erlenmeyer $300 \mathrm{ml}$, stirrer untuk mengaduk garam dalam air suling. (Badan Standart Nasional 2010).
Tabel 1

Komponen titrator otomatis.

\begin{tabular}{lll}
\hline No & Komponen Alat & Jumlah \\
\hline 1 & Modul sensor warna RGB TCS230 & 1 unit \\
2 & $\begin{array}{l}\text { Modul Arduino UNO R3 dengan chip } \\
\text { mikrokontroler ATMega328P }\end{array}$ & 2 unit \\
3 & Peristaltik pump 6 V DC, flow rate 100 ml/min & 3 unit \\
4 & Modul LCD 2 x 16 & 1 unit \\
5 & Modul motor driver dengan chip L293D & 1 unit \\
6 & Modul keypad 3 x 4 & 1 unit \\
7 & Modul buzzer aktiif dengan 5 V DC & 1 unit \\
8 & Modul magnetic stirrer 2000 rpm max & 1 unit \\
9 & Modul power supplay 5 V DC 1 A & 1 unit \\
10 & Modul power supplay 12 V DC 1 A & 1 unit \\
11 & Modul sumber cahaya RGB & 1 unit \\
12 & Beker glass 150 mL & 1 unit \\
\hline
\end{tabular}

\subsection{Pelaksanaan penelitian}

Penelitian ini diawali dengan membuat flow diagram proses dan desain alat, kemudian dilanjutkan dengan membuat/merancang alat uji dan melakukan trial diikuti dengan validasi alat uji. Hasil uji dari titrator ini juga dibandingkan dengan hasil uji yang dilakukan secara 
titrasi manual. Diagram tahapan proses penelitian seperti pada Gambar 2.

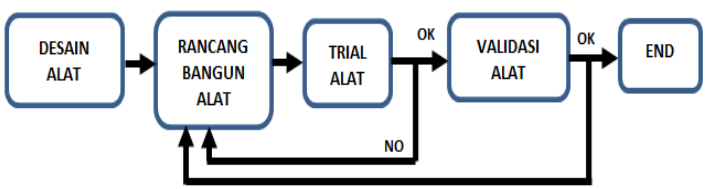

Gambar 2. Diagram alir penelitian

Titrator otomatis ini dilengkapi dengan 3 tabung yang berisi $\mathrm{H}_{3} \mathrm{PO}_{4} 85 \%$, amylum dan $\mathrm{Na}_{2} \mathrm{~S}_{2} \mathrm{O}_{3} 0,005 \mathrm{~N}$. Tabung tersebut dilengkapi dengan pompa peristaltic untuk meneteskan masing-masing reagen sesuai dengan urutannya. Selain itu alat ini juga dilengkapi dengan magnetic stirrer yang berfungsi untuk menghomogenkan reagen yang ditambahkan ke dalam sampel. Volume $\mathrm{Na}_{2} \mathrm{~S}_{2} \mathrm{O}_{3} \quad 0,005 \mathrm{~N}$ yang digunakan untuk menitrasi sampel garam konsumsi beriodium hingga tercapai endpoint, diinfokan oleh sensor ke mikrokotnroler untuk dihitung kadar $\mathrm{KIO}_{3}$ nya dan ditampilkan di LCD.

Validasi alat dilakukan dengan membandingkan hasil uji $\mathrm{KIO}_{3}$ dalam garam konsumsi beriodium dengan menggunakan alat uji titrator otomatis dan dengan menggunakan metode SNI 3556-2010. Sekumpulan data tersebut diolah dengan menggunakan perhitungan statistik. Selain itu juga dilakukan uji akurasi, presisi dan reproducibility untuk pengujian performa titrator.

\subsection{Uji akurasi}

Akurasi adalah indikator yang menyatakan seberapa dekat nilai yang diberikan oleh sistem instrumentasi terhadap nilai sebenarnya. Sedangkan Error adalah selisih antara hasil pengukuran dengan nilai kuantitas besaran yang diukur.

Error $=$ Hasil pengukuran - Nilai sebenarnya

Untuk menguji akurasi ini bisa menggunakan sampel garam konsumsi beriodium yang diuji kadar $\mathrm{KIO}_{3}$ dengan menggunakan metode SNI 3556 : 2010. Hasil dari pengujian dapat dihitung dengan menggunakan rumus 2 .

$$
\% \mathrm{R}=\frac{X a}{\mathrm{Xb}} \times 100 \%
$$

$\mathrm{R}=$ perolehan kembali (Recovery)

$\mathrm{Xa}=$ konsentrasi $\mathrm{KIO}_{3}$ dari titrator otomatis

$\mathrm{Xb}=$ konsentrasi $\mathrm{KIO}_{3}$ dari pengujian secara manual

Syarat kebertermiaannya adalah jika hasil perhitungan $\% \mathrm{R}$ berada dalam range $85 \%<\% \mathrm{R}<115 \%$ maka pengukuran dapat diterima keakurasiannya (Utami., 2017).

\subsection{Uji repeatability}

repeatability adalah kemampuan instrument untuk menghasilkan nilai yang sama untuk pengukuran berulang terhadap sebuah variable. Metode yang digunakan untuk uji repeatability ini adalah dengan menyiapkan 7 sampel yang mempunyai konsentrasi $\mathrm{KIO}_{3}$ yang sama, kemudian ketujuh sampel tersebut di ukur konsetrasinya dengan menggunakan alat tersebut dan dihitung standard deviasi dan koefisien horwitznya. Rumus yang digunakan adalah seperti rumus 3, 4 dan 5 .

$$
R S D=\frac{\mathrm{SD}}{\mathrm{Xr}} \times 100 \%
$$

RSD adalah relative standar deviation SD adalah standard deviation

$\mathrm{Xr}$ adalah rata rata konsentrasi sampel

$$
\text { CV horwitz }=2^{\left(1-\left(0.5 * \operatorname{LOG}\left(\mathrm{Xr} * 10^{-6}\right)\right.\right.}
$$

$\mathrm{CV}$ adalah coefficient variance

$\mathrm{Xr}$ adalah konsentrasi rata-rata $\mathrm{KIO}_{3}$

$$
\mathrm{CV} \text { repeatability }=\frac{2}{3} \mathrm{x} \text { CV horwitz }
$$

$\mathrm{CV}$ adalah coefficient variance

Syarat keberterimaan uji presisi jika hasil hasil peritungan \% RSD contoh < CV Repeatability, maka uji repeatability metode dapat diterima (Utami., 2017)

\subsection{Uji reproducibility}

Reproducibility adalah kemampuan instrument untuk menghasilkan output yang sama jika input sistem konstan dilepaskan dan dipasang kembali. Metode uji reproducibility hampir sama dengan metode repeatability, akan tetapi pelaksanaan pengujian boleh dilakukan oleh dua analis yang berbeda atau pada waktu yang berbeda. Syarat keberterimaan reproducibility adalah jika \%RSD $<0.67 \mathrm{CV}$ horwitz, maka uji reproducibility metode dapat diterima (Utami., 2017).

\section{Hasil dan pembahasan \\ 3.1. Rancang bangun alat uji titrator otomatis}

Titrator otomatis untuk pengujian $\mathrm{KIO}_{3}$ dalam garam konsumsi beriodium ini dibangun dengan menggunakan modul arduino UNO R3 ATmega328P. Arduino adalah sebuah platform komputasi fisik open source berbasis rangkaian input / output sederhana (I/O) dan lingkungan pengembangan yang mengimplementasikan bahasa processing (Sokop et al., 2016) Arduino dapat digunakan untuk mengembangkan obyek interaktif mandiri atau dapat dihubungkan ke perangkat lunak, merupakan modul siap pakai dari mikrokontroller AT mega 328PPU. Modul ini juga merupakan open source dimana skematik telah disediakan (S.A.Nugroho, I K.D. Suryawan, 2015). Sensor warna yang digunakan adalah TCS 230 yang dilengkapi dengan breakout board TCS 230. Berikut ini adalah gambar rangkaian modul arduino dan mikrokontroler (Gambar 3).

Gambar 4 dan Gambar 5 adalah perencanaan / gambar dari alat uji titrator otomatis $\mathrm{KIO}_{3}$. Di mana alat uji terdiri dari 3 ruangan, yaitu ruangan untuk 
menyimpan botol reagen Natrium Tiosulfat $\left(\mathrm{Na}_{2} \mathrm{~S}_{2} \mathrm{O}_{3}\right)$, botol amylum dan botol asam phospat pekat $\left(\mathrm{H}_{3} \mathrm{PO}_{4}\right)$ $85 \%$. Sedangkan dua ruang yang lain untuk ruang selang
/ saluran reagen yang akan diteteskan beserta rangkaian mikrokontroler dan ruang untuk meletakkan sampel uji dan sumber cahaya LED.
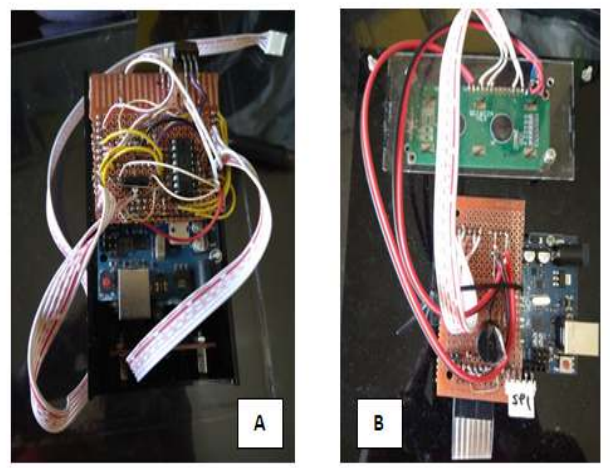

Gambar 3. (A) Rangkaian arduino (B) Rangkaian mikrokontroler

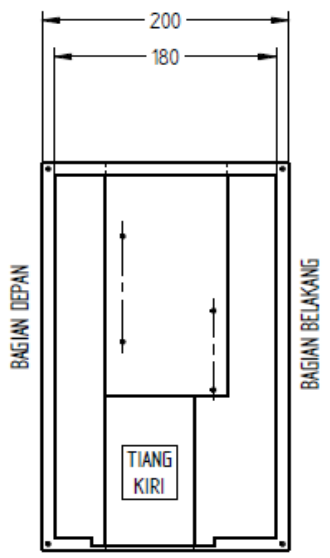

(A)

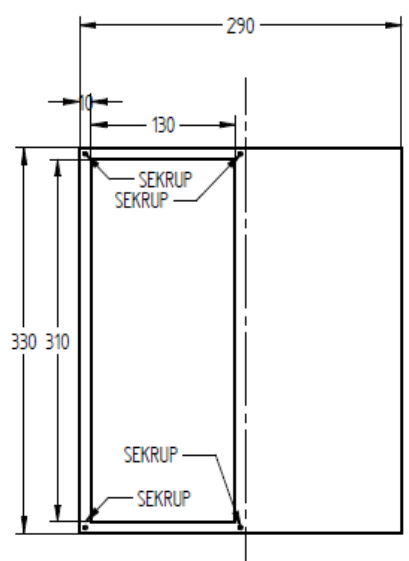

(B)

Gambar 4. Titrator otomatis tampak samping (A) dan belakang (B)

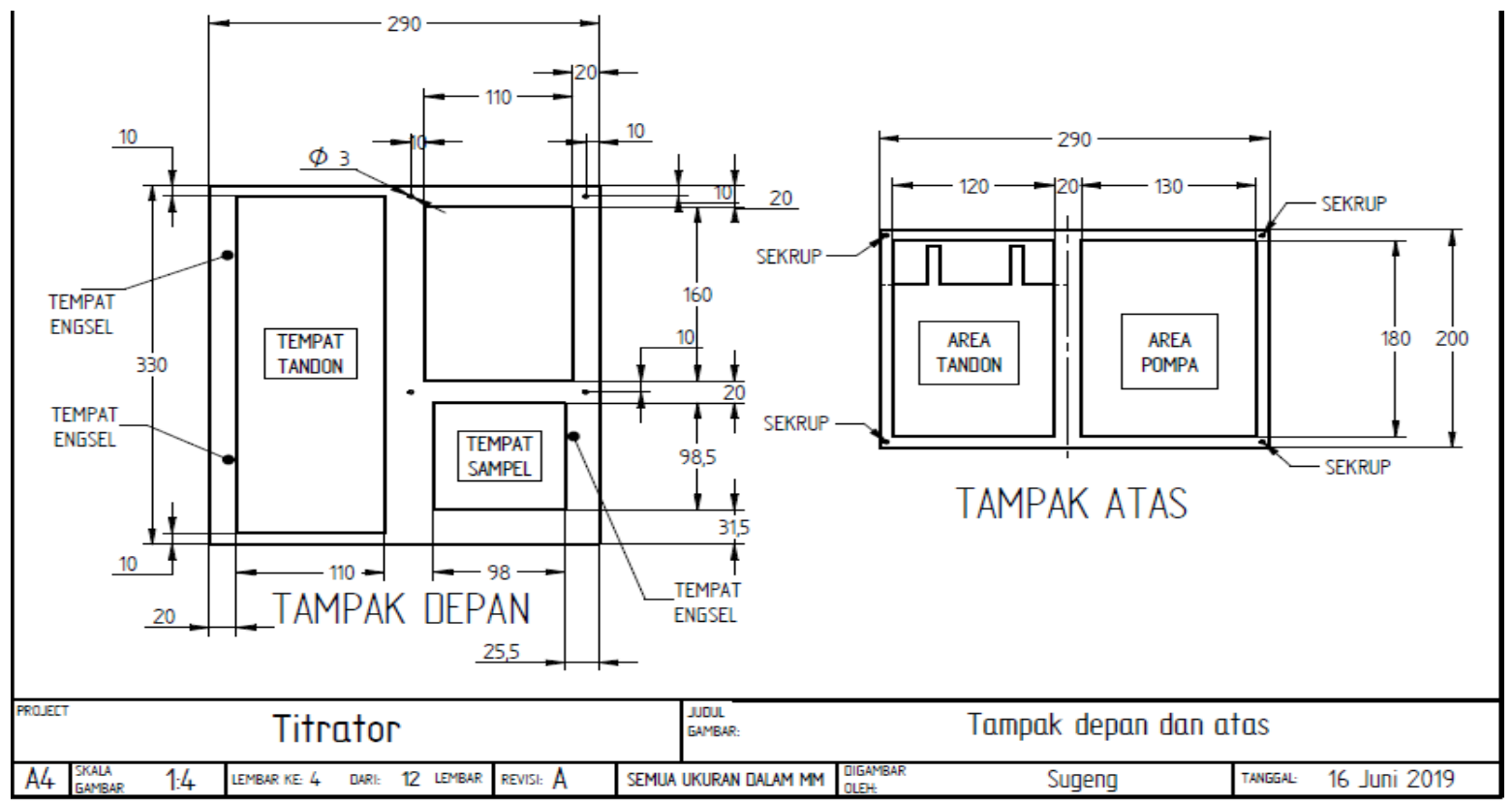

Gambar 5. Gambar desain titrator otomatis tampak depan dan atas 


\subsection{Spesifikasi alat dan manual operasional alat uji titrator otomatis}

Alat uji titrator otomatis mempunyai daya input 100 watt dan tegangan 220 volt. Spesifikasi alat uji seperti yang ditunjukkan Tabel 2. Pada display alat uji ini terdapat 3 opsional menu, yaitu : (1) Titrasi , (2) Cek dan (3) Kuras. Menu (1) Titrasi digunakan untuk melakukan pengujian / titrasi $\mathrm{KIO}_{3}$ dalam garam konsumsi beriodium. Menu (2) cek, digunakan untuk melakukan kalibrasi tetesan Natrium Tio Sulfat $\left(\mathrm{Na}_{2} \mathrm{~S}_{2} \mathrm{O}_{3}\right)$ yang keluar dari pompa peristaltic. Kalibrasi dilakukan dengan mengukur volume tetesan pompa peristaltic menggunakan pipet ukur. Sedangkan menu (3) Kuras, digunakan untuk menguras sisa larutan yang ada di dalam saluran / untuk memompa larutan dalam botol reagen supaya mengalir ke dalam saluran reagen masingmasing.

Manual pengoperasian alat adalah sebagai berikut :

- Garam ditimbang 25 gram dalam beker glass $150 \mathrm{ml}$ kemudian ditambahkan akuadest $125 \mathrm{ml}$ dan bubuk KI ke dalam beker glass tersebut

- Stirer dimasukkan ke dalam beker glass, kemudian diletakkan di dalam ruang spesimen. Tekan "1" (Titrasi) $\rightarrow$ titrator akan mengaduk selama +1.5 menit, kemudian $\mathrm{H}_{3} \mathrm{PO}_{4}$ menetes ke dalam bekerglass, selanjutnya amylum menetes hingga warnanya ungu, tiosulfat akan menetes sampai warna larutan bening

- Setelah bening, alarm alat akan berbunyi, "tit-tit-tit"

- Setelah titrasi berhenti, tekan \# masukkan data massa garam

- Tekan \# masukkan data vol titrasi standard $\mathrm{NaCl}$

- Tekan \# alat akan menunjukkan kadar $\mathrm{KIO}_{3}$

- Tekan \# untuk kembali ke menu utama

Tabel 2

Spesifikasi teknis alat uji titrator otomatis.

\begin{tabular}{ll} 
No & Spesifikasi teknis \\
\hline 1 & Daya Input : $100 \mathrm{~W}$ \\
2 & Tegangan : $220 \mathrm{Volt}$ \\
3 & Kecepatan Aduk : $0-1250 \mathrm{rpm}$ \\
4 & Flowrate : $1-100 \mathrm{ml} / \mathrm{menit}$ \\
5 & Akurasi tetesan : $0.0175 \mathrm{ml}$ \\
6 & Durasi Pengujian : \pm 6 menit \\
\hline
\end{tabular}

\subsection{Trial pengujian dan verifikasi hasil uji 3.3.1. Uji akurasi}

Uji Coba pengujian dilakukan dengan membandingkan pengujian $\mathrm{KIO}_{3}$ menggunakan titrator otomatis dan dengan menggunakan titrasi manual sesuai SNI 3556 : 2010. Hasil uji $\mathrm{KIO}_{3}$ dengan titrasi manual ditampilkan pada Tabel 3. Hasil uji $\mathrm{KIO}_{3}$ dalam sampel seperti Tabel 4 dan Pengujian menggunakan titrator otomatis pada Tabel 5. Perhitungan akurasi dari pengujian $\mathrm{KIO}_{3}$ dengan menggunakan Titrator Otomatis seperti Tabel 6. Tabel 6 menunjukkan bahwa alat uji titrator otomatis dapat memberikan nilai akurasi yang cukup baik, dimana \% $\mathrm{R}$ pengujian masuk dalam range syarat keberterimaan, yaitu diantara $85 \%$ sampai dengan 115\% (Utami., 2017).
Tabel 3

Hasil uji standardisasi natrium tio sulfat.

\begin{tabular}{llll}
\hline $\mathrm{NaCl}$ & Massa $\mathrm{NaCl}(\mathrm{g})$ & $\mathrm{Vol}$ Titrasi $(\mathrm{mL})$ & $\begin{array}{l}\mathrm{Normalitas} \\
\mathrm{Na}_{2} \mathrm{~S}_{2} \mathrm{O}_{3}\end{array}$ \\
\hline 1 & 25,0350 & 5,06 & 0,0049 \\
2 & 25,0763 & 5,10 & 0,0049 \\
\hline
\end{tabular}

Tabel 4

Hasil uji $\mathrm{KIO}_{3}$ secara titasi manual.

\begin{tabular}{llll}
\hline Sampel & $\begin{array}{l}\text { Massa Garam } \\
(\mathrm{g})\end{array}$ & $\begin{array}{l}\text { Vol Titrasi } \\
(\mathrm{mL})\end{array}$ & $\begin{array}{l}\mathrm{Kadar} \mathrm{KIO}_{3} \\
(\mathrm{mg} / \mathrm{kg})\end{array}$ \\
\hline 1 & 25,1351 & 6,22 & 43,35 \\
2 & 25,1119 & 6,38 & 44,50 \\
3 & 25,0495 & 6,36 & 44,48 \\
\hline
\end{tabular}

Tabel 5

Hasil uji $\mathrm{KIO}_{3}$ dengan menggunakan titrator otomatis.

\begin{tabular}{clll}
\hline Sampel & $\begin{array}{l}\text { Massa Garam } \\
(\mathrm{g})\end{array}$ & $\begin{array}{l}\text { Vol Titrasi } \\
(\mathrm{mL})\end{array}$ & $\begin{array}{l}\mathrm{Kadar} \mathrm{KIO}_{3} \\
(\mathrm{mg} / \mathrm{Kg})\end{array}$ \\
\hline 1 & 25 & 5,79 & 40,58 \\
2 & 25 & 6,56 & 45,90 \\
3 & 25 & 6,46 & 45,20 \\
\hline
\end{tabular}

Tabel 6

Perhitungan \% Recovery pengujian titrator otomatis.

\begin{tabular}{llll}
\hline Sampel & $\begin{array}{l}\text { Kadar } \mathrm{KIO}_{3} \\
\text { dari titrasi } \\
\text { manual } \\
(\mathrm{mg} / \mathrm{kg})\end{array}$ & $\begin{array}{l}\text { Kadar } \mathrm{KIO}_{3} \\
\text { dari titrator } \\
\text { otomatis } \\
(\mathrm{mg} / \mathrm{kg})\end{array}$ & Selisih \\
\hline 1 & 43,34 & 40,58 & 2,76 \\
2 & 44,50 & 45,90 & 1,40 \\
3 & 44,48 & 45,20 & 0,72 \\
\hline Rata-rata & 44,11 & 43,89 & \\
\hline$\%$ Recovery & 99,52 & \\
\hline Syarat & $85 \%<\% \mathrm{R}<115 \%$ & \\
\hline Keberterimaan & \multicolumn{4}{l}{ Akurasi dari alat uji diterima } \\
\hline Kesimpulan
\end{tabular}

\subsubsection{Uji presisi}

Uji presisi dilakukan dengan menyiapkan 8 sampel yang sama kemudian diuji dengan menggunakan metode titrator otomatis. Uji ini dilakukan untuk mengetahui kemampuan instrument dalam menghasilkan nilai yang seragam dalam pengukuran berulang-ulang. Sebelum dilakukan pengujian sampel, dilakukan titrasi standard $\mathrm{NaCl}$ dengan menggunakan titrator otomatis. Kemudian volume yang didapatkan dalam titrasi $\mathrm{NaCl}$ tersebut menjadi inputan data dalam pengujian titrator otomatis. Dalam uji presisi kali ini, volume titrasi $\mathrm{NaCl}$ didapatkan $6.02 \mathrm{~mL}$, sedangkan hasil uji $\mathrm{KIO}_{3}$ adalah sebagai berikut: 
Tabel 7

Hasil perhitungan uji presisi.

\begin{tabular}{|c|c|c|c|c|}
\hline No & $\begin{array}{l}\text { Kadar } \\
\mathrm{KIO}_{3} \\
(\mathrm{X}) \\
(\mathrm{mg} / \mathrm{k} \\
\mathrm{g})\end{array}$ & $\begin{array}{l}(\mathrm{X}- \\
\mathrm{Xr})^{\wedge} 2\end{array}$ & $\% \mathrm{R}^{*}$ & $\begin{array}{l}\text { Keberteri- } \\
\text { maan } \\
85 \%< \\
\% \mathrm{R}<115 \%\end{array}$ \\
\hline 1 & 32,0 & 1024 & 94,12 & Diterima \\
\hline 2 & 31,0 & 961 & 91,18 & Diterima \\
\hline 3 & 33,1 & 1095,6 & 97,35 & Diterima \\
\hline 4 & 35,2 & 1239,0 & 103,53 & Diterima \\
\hline 5 & 31,1 & 967,2 & 91,47 & Diterima \\
\hline 6 & 33,1 & 1095,6 & 97,35 & Diterima \\
\hline 7 & 33,2 & 1102,2 & 97,65 & Diterima \\
\hline 8 & 31,9 & 1017,6 & 93,82 & Diterima \\
\hline $\begin{array}{l}\text { Rata Rata } \\
(\mathrm{Xr})\end{array}$ & 32,575 & & & \\
\hline SD & 1,377 & & & \\
\hline $\begin{array}{l}\text { CV } \\
\text { (RSD) })_{\text {contoh }}\end{array}$ & 4,23 & & & \\
\hline $\mathrm{CV}$ horwitz & 9,47 & & & \\
\hline $\begin{array}{l}\text { CV } \\
\text { repeatability }\end{array}$ & 6,314 & & & \\
\hline $\begin{array}{l}\text { Syarat } \\
\text { Keberteri- } \\
\text { maan }\end{array}$ & \multicolumn{4}{|c|}{$\begin{array}{l}\text { RSD contoh }<\text { CV Repeatability } \\
4,23<6,31\end{array}$} \\
\hline
\end{tabular}

Tabel 7 menunjukkan bahwa titrator otomatis dapat memberikan keseragaman nilai yang dapat diterima, begitu juga akurasi hasil uji bila dibandingkan dengan hasil uji dari titrasi manual, memberikan nilai \% $\mathrm{R}$ antara $91,18 \%$ sampai dengan 103,53\%, masih memenuhi persyaratan keberterimaan akurasi pengujian $(85 \%<\% \mathrm{R}$ $<115 \%$ ). Namun dalam pelaksanaan uji presisi ini, ditemui kendala, dimana instrument titrator otomatis tidak dapat digunakan secara terus menerus tanpa direstart (mematikan alat) terlebih dahulu sebelum melangkah ke pengujian berikutnya. Jika tidak direstart terlebih dahulu alat menunjukkan kondisi error.

\subsubsection{Uji reproducibility}

Reproducibility adalah kemampuan instrument untuk menghasilkan output yang sama ketika pengujian dilakukan oleh dua analis yang berbeda atau pada waktu yang berbeda. Hasil uji reproducibility pengujian $\mathrm{KIO}_{3}$ menggunakan titrator otomatis seperti pada Tabel 8. Dari Tabel 8 dapat disimpulkan bahwa uji reproducibility titrator otomatis memenuhi syarat keberterimaan. Dengan demikian dapat disimpulkan bahwa alat uji ini mempunyai kehandalan dalam memberikan nilai uji. Tidak memberikan pengaruh yang signifikan terhadap perubahan manusia maupun perubahan waktu dalam penggunaannya.
Tabel 8

Hasil uji reproducibility pengujian titrator otomatis.

\begin{tabular}{|c|c|c|}
\hline & Analis 1 & Analis 2 \\
\hline Ulangan Sampel & $\begin{array}{l}\text { Konsentrasi } \\
(\mathrm{mg} / \mathrm{L})\end{array}$ & $\begin{array}{l}\text { Konsentrasi } \\
(\mathrm{mg} / \mathrm{L})\end{array}$ \\
\hline 1 & 36,0 & 37,56 \\
\hline 2 & 38,8 & 37,50 \\
\hline 3 & 37,4 & 38,70 \\
\hline 4 & 37,7 & 37,80 \\
\hline 5 & 38,6 & 38,80 \\
\hline 6 & 37,65 & 37,40 \\
\hline 7 & 38,46 & 38,50 \\
\hline Rata Rata & 37,80 & 38,04 \\
\hline SD & 0,958 & 0,607 \\
\hline$\%(\mathrm{RSD})$ contoh & 2,353 & 1,597 \\
\hline $\mathrm{CV}$ horwitz & 9,261 & 9,253 \\
\hline $0,5 \mathrm{CV}$ horwitz & 4,631 & 4,626 \\
\hline $\begin{array}{l}\text { Syarat Keberterimaan } \\
\% \mathrm{RSD}<0,5 \mathrm{CV} \text { horwitz }\end{array}$ & DITERIMA & DITERIMA \\
\hline \multicolumn{3}{|l|}{$\begin{array}{l}\text { Reproducibility } 14 \\
\text { data : }\end{array}$} \\
\hline Rata Rata & 37,92 & \\
\hline SD & 0,780 & \\
\hline$\%(\mathrm{RSD})$ contoh & 2,058 & \\
\hline $\mathrm{CV}$ horwitz & 9,258 & \\
\hline 0,5 CV horwitz & 6,202 & \\
\hline $\begin{array}{l}\text { Syarat Keberterimaan } \\
\% \text { RSD }<0,5 \mathrm{CV}_{\text {horwitz }}\end{array}$ & DITERIMA & \\
\hline
\end{tabular}

\section{Kesimpulan}

Titrator otomatis $\mathrm{KIO}_{3}$ memberikan hasil uji yang akurat dan presisi. Titrator otomatis dapat menghasilkan nilai pengujian $\mathrm{KIO}_{3}$ yang stabil, dan mendekati nilai pengujian $\mathrm{KIO}_{3}$ secara titrasi manual (sesuai SNI 3556 : 2010). \% Recovery hasil uji akurasi mencapai 99,52\%, sedangkan uji presisi didapatkan nilai $\mathrm{RSD}_{\text {contoh }}<$

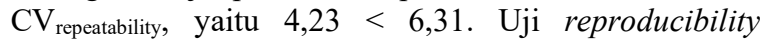
didapatkan nilai \% RSD $<0,5 \mathrm{CV}_{\text {horwitz, yaitu } 2,058<}$ 6,202 . Hasil uji verifikasi tersebut telah memenuhi syarat keberterimaan.

\section{Ucapan terima kasih}

Kami mengucapkan terimakasih kepada Bapak Aan Edy Antana selaku Kepala Baristand Industri Surabaya, Bapak Yossy Okta Ryananta selaku Kepala Seksi Teknologi Industri Baristand Industri Surabaya yang telah memberikan support terhadap penyelesaian penelitian ini, saudari Mya Sukmawati yang telah membantu melakukan pengambilan data, Saudari 
Wiwik, Saudara Syamsu dan saudara Sugeng yang telah membantu merancang penelitian ini.

\section{Daftar pustaka}

Amanati, L., 2017. Karakteristik kandungan $\mathrm{KIO}_{3}$ pada garam konsumsi beriodium yang beredar di kota Blitar. Jurnal Teknologi Proses Dan Inovasi Industri 2(2), 3-6. doi.org/10.36048/jtpii.v2i2.3506.

BSN, 2010. Standar Nasional Indonesia SNI 3556-2010, Garam konsumsi beriodium. Badan Standardisasi Nasional

Ika, D., 2009. Alat otomatisasi pengukur kadar vitamin c dengan metode titrasi asam basa. Neutrino, 1(2), 163-178. doi.org/10.188860/neu.v0i0.1634

Irawati, Endang, T., Hadi, M., Widodo, T., 2011. Tingkat konsumsi garam beriodium dan kaitannya dengan gangguan akibat kekurangan iodium ibu hamil. Jurnal Gizi Klinik Indonesia 8 (1) : 1-6. doi.org/10.22146/ijen/17724

Kapantow, Nelisa, A., Yudistira, A., 2013. Identifikasi dan penetepan kalium iodat dalam garam dapur yang beredar di pasar kota bitung dengan metode spektrofotometri UV-Vis. PHARMACON. Jurnal Ilmiah Farmasi, UNSRAT 2 (01) : 90-95. doi.org/https10.35799/pha.2.2013.1253.

Kusuma, S. T., Budiono, I., 2016. Faktor konsumsi yang berhubungan dengan kejadian gangguan akibat kekurangan iodium pada anak sekolah dasar. Unhes Journal Of Public Health 5 (2): 149-55. doi.org/10.15294/ujph.v5i2.10123

Lancy, Mahlinda, 2013. Rancang bangun peralatan iodisasi garam portabel menggunakan sistem semi otomatis. Jurnal Hasil Penelitian Industri no. 26 (2) :
73-80.

Lathifah, N., 2018. Faktor yang berhubungan dengan status iodium anak usia sekolah di indonesia. Jurnal Berkala Epidemiologi 6: 147-56. doi.org/10.20473/jbe.v6i22018.147-156.

Lestari, N., 2008. Aplikasi GMP dalam produksi garam konsumsi beriodium. Jurnal Riset Teknologi Industri 2 (23) : 78-90.

Nugroho, S.A., Suryawan, I.K.D., Wardana, I.N.K., 2015. Penerapan mikrokontroler sebagai sistem kendali perangkat listrik berbasis android. Eksplora Informatika, 4(2), 135-144.

Nurmastika, A., Erwanto, D., Rosanti, A.D., Fiolana, F.A., 2018. Rancang bangun alat pengukur kadar asam askorbat pada buah dengan metode titrasi iodometri. SETRUM, 7(1), 147157.doi.org/http://dx.doi.org/10.36055/setrum,v7i1.3 401.

Rinaldo, A., Fahmi, K., Sari, L., 2018. PROSIDING SNIPS 2018 Alat pendeteksi warna dengan menggunakan sensor TCS230 Berdasarkan Warna Dasar Penyusun RGB. Prosiding SNIPS, c, 78-85. doi.org/ISBN: 978-602-61045-4-0

Romadhon, A.S., J. R. Baihaqi, J.R., 2015. Prototipe alat pemilah jeruk nipis menggunakan sensor warna TC230. Jurnal Ilmiah Mikrotek 1(4), 184-190.

Sokop, S.J., Mamahit D.J., Sherwin, R.U.A., Sompie, 2016. Trainer periferal antarmuka berbasis mikrokontroler arduino uno. Teknik Elektro Dan Komputer, 5(3), 13-23.

Utami., A. R., 2017. Verifikasi metode pengujian sulfat dalam air dan air limbah sesuai SNI 6989.20: 2009. Jurnal Teknologi Proses Dan Inovasi Indiustri, 2(1), 19-25. doi.org/10.36048/jtpii.v2i1.2726. 